\title{
PROSPECTS OF DEVELOPMENT OF INSURANCE MEDIATION IN UKRAINE
}

\author{
Ruslana Pikus', Nataliia Prykaziuk ${ }^{2}$, Nataliia Kudryavska ${ }^{3}$ \\ Taras Shevchenko National University of Kyiv, Ukraine
}

\begin{abstract}
The purpose of the paper is to explore prospects for the development of insurance mediation in Ukraine in line with the key vectors of the dynamics of the insurance mediation institute in Europe. The objectives of the article are determined by the need to analyse: the new EU Directive No. 97, the provisions of the new draft Law of Ukraine "On Insurance", and the mechanisms for introducing certification of insurance mediators in Ukraine. Methodology. General scientific and specific research methods were used for the present research. In particular, the method of synthesis and analysis was used in determining the modern approaches to addressing the key trends and prospects for the development of Ukrainian insurance mediation; comparative method was used for a comparative analysis of the specifics of the European and Ukrainian intermediary market; the method of ascending from abstract to specific was used when investigating the mechanisms of certification of insurance mediation. Results. The prospects of development of insurance mediation in Ukraine are investigated in the article. The new EU Directive No 97 and the ways of modernizing the national mediation for the latter are analysed. Mechanisms for improving the Ukrainian institute of mediation according to the European document are identified. The new draft Law of Ukraine "On Insurance" is studied taking into account the modern trends of the insurance mediation development. The necessity of adaptation of the drafted law according to demands of the new Directive is emphasized. The necessity of introduction of certification for insurance mediators is justified; the benefits of implementation of this process in practice are pointed out. Practical implications. The paper identifies the key practical issues and activities on an adaptation of Ukrainian legislation to the European regulation under the European integration processes. First of all, in the legislation of Ukraine, it is necessary to determine the individual distributors (insurance mediators) and the conditions of their registration. At the same time, the provisions on limiting the volume of insurance premiums, a list of insurance risks, regulation of insurance agents and insurance (reinsurance) brokers are the eligible issues for Ukraine nowadays. Notably, the development of mechanisms to control the efficiency, assessing the knowledge, professional training of insurance (reinsurance) mediators, and employees of insurance (reinsurance) companies is highly relevant for Ukraine. Under the condition of legislative consolidation in the insurance market of Ukraine, it is possible to establish a requirement for insurance (reinsurance) mediators, entities, for which the consignment of insurance products is not the main activity, to have an insurance policy of professional liability. Conditionally, the Code of Professional Ethics for Insurance Brokers, acting in Ukraine, is a response to the theses of the Directive on fair, just, professional actions, and their compliance with the client's interests. The question remains open on regulating the following issues at the legislative level: remuneration of insurance distributors, requirements for the compulsory conclusion of a contract on providing consumers with information on the status of the seller of the insurance product, the type of its remuneration and cross-selling. Value/originality. The paper proves a highly relevant issue for Ukraine - the implementation of the registration process for all categories of insurance mediators and the keeping track on statistics of their activities. It will justify the process of adaptation of Ukrainian legislation to the EU standards. The research results prove the great significance of the adoption of the new Law of Ukraine "On Insurance", which will allow the introduction of a new procedure for legislative regulation of insurance (reinsurance) mediation in the field of insurance; improve the system of legal support for the development of insurance mediation, its state regulation, monitoring the activities of insurers and insurance mediators. The analysis of the existing draft of the law justifies taking into account the basic recommendations of Directive 2009/138/EU
\end{abstract}

\footnotetext{
Corresponding author:

${ }^{1}$ Faculty of Economics, Taras Shevchenko National University of Kyiv.

E-mail: pikusruslana3@gmail.com

${ }^{2}$ Department of Insurance, Banking and Risk Management, Taras Shevchenko National University of Kyiv.

E-mail: pnvuniv15@ukr.net

${ }^{3}$ Faculty of Economics, Taras Shevchenko National University of Kyiv.

E-mail: natakudryavskaya@gmail.com
} 
of 2009 that is why it is necessary to align its provisions with the new Directive No. 97. The paper suggests that certification of insurance agents includes the establishment of the level of education, training, professional skills, knowledge, the experience of a professional to confirm compliance with standards, requirements as to the conduct of insurance actions. National certification conditions must be in line with EU laws. It is proved that introduction of certification of insurance agents: increases the authority of professionals in the insurance market, payment for their labour; promotes the development of the insurance market; certifies the professionalism of insurance mediators; raises trust; meets the requirements of international insurance markets and labour markets; allows assessing the quality of mediator training; provides quality services to the insured; protects against fraud by insurance mediators, insurers or insurers.

Key words: insurance mediation, insurance agent, insurance broker, new EU Directive, draft Law of Ukraine "On Insurance", certification of insurance mediators.

JEL Classification: G10, G22

\section{Introduction}

Formulation of the problem. The dynamic development of modern Ukrainian insurance mediation in Ukraine requires a scientific understanding of its prospects, analysis and definition of effective ways of improving its functioning, mechanisms of adaptation to progressive European standards. The current scientific problem in this context is to the ways of improvement of the regulatory framework for the activities of insurance mediators because they determine the new promising ways of the evolution of national mediation considering the challenges and needs of the modern world. In view of the above, there is a need to analyse the provisions of the new EU Directive No. 97 in the context of improving the regulatory framework of Ukrainian insurance mediation, the draft of the Law of Ukraine "On Insurance", prospects for certification of insurance mediators.

Analysis of recent research and publications. The analysis of present scientific problem has been provided in a number of scientific works. In particular, in these scientific works, an attention is paid to the study of mechanisms for implementing changes in the state regulation of the insurance brokerage institution in order to improve its activities (Gabidulin, 2012), the analysis of international experience of insurance mediators in projection on the ways to improve their activities in Ukraine, international practices of assessing the reliability of insurance companies and their representatives (Pikus, 2009), a comparative analysis of the regulation of the activities of insurance mediators in the world in view of the prospects of Ukrainian mediators, features of state regulation of the insurance sector of Ukraine, its trends and prospects, specifics of the activity of insurance brokers (Prykaziuk, 2010, 2013 a, 2013 b), problems of certification of insurance mediators (Prykaziuk, Gubankova, 2013), Ukrainian intermediary services in insurance, in particular, mechanisms of their adaptation to European ones (Rasshyalov, 2008), the analysis of mechanisms of regulation of insurance mediation on the territory of Ukraine in the conditions of European integration processes (Sholoyko, 2016).

Previously unsettled parts of the general problem. Existing scientific papers highlight certain aspects of the given scientific problem. Instead, there is no comprehensive research devoted to the analysis of the key prospective vectors of the insurance mediation development in Ukraine. In particular, there is no systematic study of the mechanisms of adaptation of the Ukrainian mediation institution to the provisions of the new EU Directive. The theses of the drafted Law of Ukraine "On Insurance" need scientific comments in relation to insurance mediators. The study of certification of insurance mediators, its mechanisms and possible positive effects is relevant.

The purpose of the paper is to explore prospects for the development of insurance mediation in Ukraine in accordance with the defining vectors of the dynamics of the insurance mediation institute in Europe. The objectives of the paper are determined by the need to analyse: the new EU Directive No. 97, provisions of the new drafted Law of Ukraine "On Insurance", mechanisms for introducing certification of insurance mediators in Ukraine.

\section{Comparative analysis of legislative provisions}

The strategic perspective of the development of Ukrainian insurance mediation is to bring the basis of its activities to the developed European standards. Adaptation of Ukrainian regulatory legislation to European principles requires consideration of the provisions of the new EU Directive No. 97, in particular, the maximum approximation of the work of insurance mediators to the stated requirements. Ukraine's European integration aspirations are stated in the Association Agreement between Ukraine and the European Union, the European Atomic Energy Community and their Member States (Association Agreement, 2014). The new EU Directive No. 2016/97/EU on insurance distribution (IDD) has 
abolished the provisions of the Directive 2002/92/ EU on insurance mediation. Member States should implement its theses up to 23.02.2018 (IDD. BIPAR, 2016). There are significant legislative changes among the conditions of the European document. Article 3 of Appendix XVII to the Association Agreement provides an explanation of Ukraine's actions in this situation. Adaptation to European requirements in the field of regulation of insurance mediation, strengthening of the brokerage institution, in particular, is important for the sustainability of the Ukrainian insurance market. In Ukraine, in 2006-2017, the share of insurance premiums collected by insurance brokers in general insurance premiums ranges from $0.1 \%$ to $0.4 \%$. This is a very low indicator. On average, there are about six insurance companies per one insurance broker currently. Instead, it's the other way round in the highly developed countries of the world (National Commission, 2017). The reasons for the adoption of the new Directive are clearly stated, in particular, the aim is to extend its effect to entities whose activities are to provide third parties with services for the sale of insurance and reinsurance products, that is, insurance mediators (Sholoyko, 2016). The consignment of insurance products "implies the activity of consulting, offering or undertaking other work in preparation for the conclusion of insurance contracts, the conclusion of such contracts, or the provision of assistance in the administration and execution of such contracts, in particular, in the event of losses" (IDD. BIPAR, 2016). An insurance intermediary is an "individual or legal person other than the insurance or reinsurance company or its employees and any intermediary, for whom the consignment of insurance products is an additional form of activity, which initiates or carries out activity on consignment of insurance products against commission" (IDD. BIPAR, 2016).

The new Directive provides regulation of activities of insurance and reinsurance mediators, as well as insurance distributors in general. These include the full range of entities that sell insurance products, including direct sales through insurance (reinsurance) companies, sites, price comparison sites, and other information resources. It is necessary to clearly list the entities who are distributors and insurance mediators in Ukrainian regulatory legislation. The document defines the conditions for registration of insurance distributors. It is noted that "insurance, reinsurance mediators, and intermediaries, whose additional activity is the consignment of insurance products, must be registered with the competent authority of the country of their registration" (IDD. BIPAR, 2016). The new Directive specifies the need to establish restrictions on the volume of insurance premiums, the list of insurance risks. The provisions do not apply to entities that sell insurance products, not as a primary activity. It regulates the activities of insurance agents, insurance and reinsurance brokers. In Ukraine, there are a significant number of actors involved in the consignment of insurance services. Therefore, we consider it necessary to expand the object and limits of regulation of insurance mediation, to establish restrictions on entities, for which the consignment of insurance products is the main type of activity.

The new EU Directive defines the criteria for qualification requirements and certification of insurance mediators. It is emphasized that there is a need to establish the continuous vocational training covering at least 15 hours per year. The particularity depends on the type of insurance distributor, the nature of the products it sells. The result of the successful training must be a certificate obtained by the insurance mediator. For Ukraine, the implementation of these requirements is quite possible that involves development and introduction of mechanisms for setting up the training process, evaluation criteria, and certification conditions. The important point is the requirement of the Directive to insurance (reinsurance) mediators, entities for which the consignment of insurance products is not the main activity, in possession of the policy of professional insurance liability. It is noted that "insurance and reinsurance mediators should have insurance coverage of the third-party professional liability" (IDD. BIPAR, 2016). In Ukraine, this point is envisaged in the new drafted Law of Ukraine "On Insurance" and will come into force upon its adoption. The Directive contains a list of qualifying requirements for insurance agents, which they need to conduct intermediary activities with the mandatory insurance of civil liability of motor vehicle owners (MICLMVO). Taking into account the development and variability of the insurance market, the Directive focuses on the need for continuous improvement of the skills and level of knowledge of insurance distribution companies; the regulation of compulsory insurance of professional liability of individuals whose work may be harmful to third parties. In Ukraine, this list should be determined by the government. Among the requirements for an insurance distributor, the need for honest, fair, professional actions, their compliance with the interests of the client is emphasized. The Code of professional ethics of insurance mediators in force in Ukraine correlates with this provision. The new Directive sets out the principles for remuneration of insurance distributors, specifies the requirement for the mandatory signing of a contract on providing information to consumers about the status of the provider of the insurance product, the nature of its remuneration. This provision in Ukraine is virtually unregulated at the legislative level, remaining on the agenda as a priority for implementation. The new Directive contains a cross-selling clause if the insurance product is an addition to a product or service. In this case, the insurance distributor is required to inform clients of the possibility to buy different components 
of a particular product separately. This should be accompanied by the necessary description of the various components in the contract. This issue remains unregulated in Ukraine at the legislative level.

Currently, different types of individuals and institutions, including agents, brokers, bank insurance operators, insurance companies, travel agencies, car rental companies are entitled to distribute insurance products. In order to ensure uniform standards of service and consumer rights protection by operators, it is necessary for all these entities and institutions to be subject to the new Directive. In contemporary insurance market, there are significant national norms, in particular, Ukrainian ones, which create certain obstacles for the activity on consignment of insurance (reinsurance) products in the domestic market. Therefore, the strengthening of the insurance market of Ukraine is relevant. The introduction of the provisions of the new Directive will improve the state regulation of the insurance market and maximize the scope of insurance services, primarily through the development of insurance mediation. Protecting the interests and positions of national insurers requires giving them greater rights and opportunities to combine the high level of requirements for them, as well as increasing their personal responsibility for insurance contracts.

The need for the adoption of the new Law of Ukraine "On Insurance" (Draft Law of Ukraine, 2012) is determined primarily by the outdated legislative field. The current Law of Ukraine "On Insurance" was adopted in 1996. In 2012, the new drafted law was considered and adopted by the Verkhovna Rada of Ukraine of VII Convocation in the 2 nd reading. But the powers of this convocation were terminated ahead of schedule, and the final consideration of the new law was slowed down. The length of time has aggravated the urgency and the need for its adoption. The explanatory note to the drafted law states that "an active participation of domestic insurers in international insurance relations, as evidenced by the opening and further liberalization of the Ukrainian financial market under the accession to the World Trade Organization (WTO) and the Association Agreement between Ukraine, on the one hand, and the European Union, the European Atomic Energy Community and their Member States, on the other hand, require the unification of standards of state insurance supervision and regulation in Ukraine, putting them in line with the provisions established by the International Association of Insurance Supervisors (IAIS), and directives of the European Union" (Draft Law of Ukraine, 2012). Adoption of the new wording of the Law will allow introducing a new procedure for the legislative regulation of insurance (reinsurance) and mediation in the field of insurance. This applies to residents and nonresidents on the territory of Ukraine. The system of legal support for the development of insurance mediation, its state regulation will be improved. The necessity of a new bill is conditioned by the fact that public trust in the activities of insurers and reinsurance mediators is low in Ukraine. Thus, about $30 \%$ of net insurance premiums come from insured individuals (Draft Law of Ukraine, 2012). Among the key goals and objectives of the draft law, there are the adaptation of the Ukrainian legislation in the field of insurance mediation to the European one and the improvement of the monitoring of activities of insurers and insurance mediators by state regulation.

However, the existing drafted law takes into account the basic recommendations of Directive 2009/138/EU of 2009. Therefore, it is necessary to align its provisions with the theses of the new Directive No. 97 of 2016. The existing drafted law suggests determining the procedure for regulating mediation in Ukraine in accordance with EU legislation; determining the legal status of actuaries and auditors in the field of insurance. The drafted law provides general and specific requirements for the activities of insurance brokers and insurance agencies in accordance with international principles and standards. The EU proposals on the availability of two separate accounts for brokers and insurance agencies for their own organizational and economic activity, transfer of insurance payments and insurance payments, as well as the duty of a broker or insurance agency to insure their professional liability with not less than 5 million UAH for each insured event are taken into account (Draft Law of Ukraine, 2012). A new law will substantially strengthen principles of activities of participants in the insurance market, in particular, those of agents and brokers. Here the principles of mediation in insurance, the peculiarities of state regulation and supervision are determined. Intermediary activities in insurance are defined as "activities for the remuneration for consulting, offering, preparing, arranging, and maintaining insurance (reinsurance) contracts, as well as other actions aimed at the conclusion, execution, and payment of such contracts, including the determination of the degree of insurance risk, its evaluation and analysis, registration of documents and participation in accruals on payments of insurance (reinsurance) premium and/or insurance (reinsurance) remuneration" (Draft Law of Ukraine, 2012). An insurance agent is defined as "a person, who carries out mediator insurance activities for remuneration and acts on behalf of or in the interests of the insurer or insurance agency and does not participate in the calculation of insurance payment" (Draft Law of Ukraine, 2012). An insurance broker is an individual entrepreneur, a legal entity, or a permanent representation of an insurance and/or reinsurance broker, a non-resident, which carries out mediator activities in the field of insurance (reinsurance) for remuneration and whose information is included in the state register of insurance brokers" (Draft Law of Ukraine, 2012). Insurance mediators include insurance brokers and insurance agents. Section VII is devoted to the definition of the framework of their 
activities. Mediator insurance activities can be carried out by insurance agents; insurance agencies included in the State Register of Insurance Mediators; insurance brokers included in the State Register of Insurance Mediators; insurance and/or reinsurance brokers (non-residents who, in accordance with the established procedure, have indicated their intention to engage in activities in Ukraine). The drafted law suggests, in accordance with European standards, such a definition of the functions of insurance intermediaries - "to provide consultations, perform other preparatory work for the conclusion of insurance and/or reinsurance contracts, or concluding such agreements and assistance in the administration and execution of such contracts, in particular, participation in the investigation in the case of an insured event and the settlement of a loss performed by the insurer or employees of the insurer, is not considered as a mediation" (Draft Law of Ukraine, 2012). It is emphasized on the necessity to carry out mediator activities in accordance with the terms of the agreement between the insurance mediator and the insurer; it is suggested to create the conditions for the maximum availability of information concerning nonresident brokers, in particular, to make it public on the official website of the Authorized Agency. Article 80 describes the requirements for an insurance broker and an insurance agency. In particular, the head of an insurance broker, insurance agent, insurance broker (individual entrepreneur) must meet the following requirements: legally competent, higher education or experience in the field of insurance (reinsurance) of at least 2 years; the absence of a conviction non-cancelled or not taken off in the manner established by law for the intentional crimes in the field of economic and service activities; during the last 5 years, can not to be the head, head accountant of legal entities recognized as bankrupt or subjected to the procedure of forced liquidation during the period of their stay in such positions (Draft Law of Ukraine, 2012) (see Figure 1).

The principles of inclusion in the State Register of Insurance Mediators are set out in Article 81. The positive aspect of the drafted law is the means of regulating the activities of insurance mediators, their accountability (Article 83). Article 85 describes the

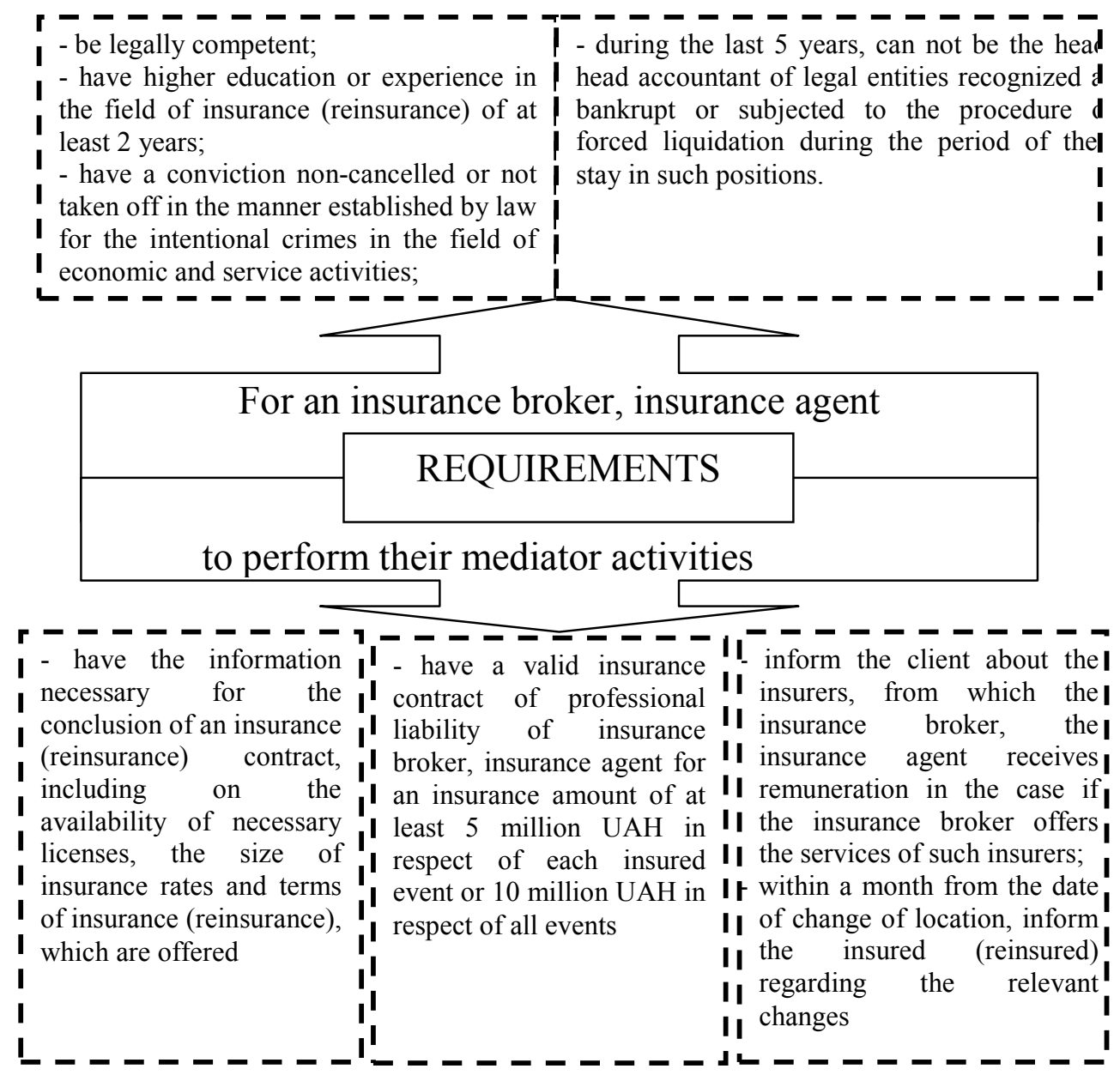

Fig. 1. Requirements for an insurance broker and insurance agent for performing their intermediary activities

Source: compiled by authors according to (Draft Law of Ukraine, 2012) 
requirements for the procedure for the mediator activity of an insurance broker and insurance agency.

Article 86 describes the requirements for the procedure of mediator activities of insurance agents, in particular, the obligation of the insurer to conclude an agreement with his insurance agent, which specifies the scope of the activity of the insurance agent, classes of insurance; the size of the maximum insured amount; agent's authority. Article 102 defines the fundamentals of state supervision of insurance brokerage activities, in particular, revisions (inspections) of insurers, insurance brokers by representatives of the authorized authority or auditors. Consequently, the new drafted Law of Ukraine "On Insurance" advances the activities of Ukrainian insurance mediators to European regulations and standards. Nevertheless, it is necessary to harmonize its provisions with the theses of the new EU Directive No. 97. The key differences that exist in the new EU Directive, the drafted Law of Ukraine "On Insurance" and the current national insurance mediator legislation are summarized in Table 1.

\section{The issue of the insurance mediators' certification}

Their certification is relevant in the context of prospects for the development of Ukrainian insurance mediation. State registration is mandatory for insurance brokers of Ukraine, which concerns legal entitiesentrepreneurs, citizens-entrepreneurs, who are officially registered in the state register of insurance brokers of
Ukraine; representative offices of foreign insurance brokers registered in Ukraine as taxpayers, and in the state register of insurance brokers. As for insurance agents, they are not required to register. This applies to legal entities-entrepreneurs, for whom mediation in the insurance market is an exclusive type of activity (insurance agencies); legal entities - subjects of entrepreneurial activity, for which mediator activity in the insurance market is not an exclusive type of activity (travel agencies, consulting firms, transport and shipping organizations, law offices, etc.); citizen entrepreneurs who work with the insurance company on the basis of an agency agreement; individuals who carry out their activities as insurance agents under a contract with an insurance company; insurance companies-residents who implement insurance services of foreign insurers under the terms of an agency agreement; specialized associations of insurers with the right to implement insurance services of members of the association; representative offices of foreign insurance agents - legal entities registered in Ukraine as taxpayers; representatives of foreign insurance agents of individualsentrepreneurs (Prykaziuk, Gubankova 2013). Certification has a positive effect on the development of insurance mediation and the insurance market in general. Researchers highlight the following advantages in introducing certification of insurance agents: "1) increased demand and "value" of professionals in the labour market, 2) development of a positive image in the insurance market, 3) demonstration of the qualification reliability of insurance mediators; 4) compliance with

Table 1

Comparative analysis of the regulation of insurance mediation under the new EU Directive, the drafted Law of Ukraine "On Insurance”, and the current legislation

\begin{tabular}{|c|c|c|}
\hline EU Directive & Drafted Law of Ukraine "On Insurance" & Current legislation on insurance mediation \\
\hline 1. Distribution in insurance; & 1. Mediation in insurance; & 1. Mediation in insurance; \\
\hline $\begin{array}{l}\text { 2. Necessity of registration of insurance } \\
\text { distributors with the competent authority; }\end{array}$ & $\begin{array}{l}\text { 2. Existing provision for compulsory } \\
\text { registration of insurance agents and insurance } \\
\text { brokers with the competent authority; }\end{array}$ & $\begin{array}{l}\text { 2. Mandatory registration only for insurance } \\
\text { brokers with the competent authority; }\end{array}$ \\
\hline $\begin{array}{l}\text { 3. Established criteria for the qualification } \\
\text { requirements and certification of insurance } \\
\text { mediators; }\end{array}$ & $\begin{array}{l}\text { 3. Established quality requirements for } \\
\text { agents and brokers; }\end{array}$ & $\begin{array}{l}\text { 3. There are no clear requirements regarding } \\
\text { the qualifications of agents and brokers; }\end{array}$ \\
\hline $\begin{array}{l}\text { 4. The norm on continuous professional } \\
\text { training; }\end{array}$ & $\begin{array}{l}\text { 4. Introduces the provision on compulsory } \\
\text { professional training; }\end{array}$ & $\begin{array}{l}\text { 4. There is no compulsory professional } \\
\text { training; }\end{array}$ \\
\hline $\begin{array}{l}\text { 5. Obligatory professional liability insurance } \\
\text { policy; }\end{array}$ & $\begin{array}{l}\text { 5. Introduces a clause on an obligatory } \\
\text { policy of insurance of professional liability of } \\
\text { intermediaries; }\end{array}$ & $\begin{array}{l}\text { 5. There is no obligatory policy of insurance } \\
\text { professional liability; }\end{array}$ \\
\hline $\begin{array}{l}\text { 6. Requirement of fair, just, professional } \\
\text { actions in accordance with the interests of } \\
\text { the client; }\end{array}$ & $\begin{array}{l}\text { 6. Requirements to insurance intermediaries } \\
\text { contain provisions regarding the } \\
\text { correspondence of their professional } \\
\text { activities to the interests of clients; }\end{array}$ & $\begin{array}{l}\text { 6. Code of professional ethics of insurance } \\
\text { intermediaries is in force; }\end{array}$ \\
\hline $\begin{array}{l}\text { 7. Compulsory conclusion of a contract } \\
\text { on the provision of consumers with } \\
\text { information regarding the status of the seller } \\
\text { of the insurance product, the type of its } \\
\text { remuneration. }\end{array}$ & $\begin{array}{l}\text { 7. Provision is made for the mandatory } \\
\text { conclusion of such an agreement. }\end{array}$ & $\begin{array}{l}\text { 7. There are no provisions on the mandatory } \\
\text { conclusion of such an agreement }\end{array}$ \\
\hline
\end{tabular}

Source: compiled by the authors according to (Draft Law of Ukraine, 2012; IDD. BIPAR, 2016) 
the requirements of international labour markets; 5 ) opportunity to obtain an independent assessment of the quality of mediator training; 6) provision of quality services to the policyholder; 7) protection against fraud by insurance mediators, insuring party or insurers" (Prykaziuk, Gubankova, 2013).

Regarding the prospects of certification of insurance intermediaries as an important requirement for ensuring the efficiency and qualification of their activities, we see the following ways and mechanisms for its implementation. First: the creation of a working group that includes representatives of the Ministry of Finance, the National Financial Services Commission, associations of insurance mediators and insurers, independent experts. The purpose of the activity is to develop the concept of a state program for the development of insurance mediation in Ukraine, the certification of insurance intermediaries, in particular. Second: the introduction of registration of all categories of insurance mediators. Third: a systematic publication of insurance brokers' statistics; activation of publications devoted to issues of insurance mediation in the media. The experience of other countries with a highly developed insurance market with certification of insurance agents will be useful, namely, establishing the full compliance of the qualitative characteristics of the insurance mediator (its level of education and professionalism) with the latest world requirements and standards. We believe that the certification of insurance agents is not a competency test, the purpose of which is to determine the professionalism of the agent in accordance with the position that he occupies. In our opinion, the task and purpose of certification are to establish the level of education, training, professional skills, knowledge, the experience of a professional to confirm his compliance with certain standards, requirements for the conduct of the insurance operations. If the competency test of insurance agents is carried out by the employer, then their certification must be carried out by the relevant certification body (third party) (Certification Association "Russian Registry", 2015).

Different provisions regarding the certification of insurance mediators are typical for world practice. There are several ways to certify insurance mediators that are carried out in different places: the school of insurance mediators; association of entities of insurance activity; certification body for insurance mediators; state supervisory authority. Legislation of the EU states has clear requirements for certain insurance agents to undergo special training. Each country has specific features related to the certification of insurance mediators, which are determined by the type of insurance. Types of certification of insurance mediators in the USA are particularly common, where they are certified for life insurance, accident, health; property and liability; car rental; real estate insurance; bail; one type of insurance; insurance of individuals. The certification process has a positive effect on the development of insurance mediation (Prykaziuk, Gubankova 2013).

Consequently, the introduction of certification of insurance mediators enables them to increase their credibility in the market and trust them from the side of clients; increase the payment of their labour; promotes the development of the insurance market; certifies the professionalism of insurance mediators; meets the requirements of international insurance markets and labour markets; gives an opportunity to independently evaluate the quality of mediator training; provides quality services to the insured; protects against fraud by insurance mediators, insuring party or insurers (Prykaziuk, Gubankova 2013).

After the adoption of the new Tax Code of Ukraine on 01.01.2012, the status of insurance agents has changed. From now on, they must be full-time employees of insurance companies or work under a simplified taxation system, according to which the payment of $5 \%$ of the commission fee is obligatory (Tax Code of Ukraine: Law of Ukraine, 2010). In essence, the first option for the entry of insurance agents to the staffing of insurance companies did not work. This leads to an additional payment of contributions to state funds by the insurers, which is $36.76 \%$ and cannot be profitable for insurance companies. Regarding the second option, it complicates the activities of insurance agents, which should be registered as subjects of entrepreneurial activity. The latter leads to the mandatory monthly payment of contributions and independent accounting. Given this, as well as the specifics of the national insurance market, such steps will lead to the fact that insurance agents will receive significantly lower insurance premiums. The development of agent activities is a relevant problem. After all, many insurance agents also perform the functions of the broker, working with several insurance companies; insurance agents are not always responsible to the insured; there is no training of insurance agents aimed at the professional consignment of insurance products. The need for certification of insurance agents for all types of insurance is growing. This will enable raising the culture of the insurance market in general and solve many problems. By this time, the Ukrainian insurance market has a low level of public confidence in insurance agents and their activities. This problem can also be solved by the introduction of certification of insurance agents in Ukraine.

\section{Findings}

It is important to approve the certification procedure for insurance agents and implement it in practice. This is a lengthy process that can be implemented in several stages. We see such mechanisms and prospects for implementing this process in practice. First: 
the development of a comprehensive training and testing program for insurance agents, which would include their general training and training in majors. The association of insurance industry participants is to be among the developers of such a program, in particular, the League of Insurance Organizations of Ukraine, the Ukrainian Federation of Security, the Federation of Insurance Mediators of Ukraine, the Motor (Transport) Insurance Bureau of Ukraine, the National Commission for State Regulation in the Financial Services Markets, and others. Second: on the basis of the Law of Poland "On Insurance Mediation", taking into account its achievements and taking into account the Ukrainian insurance market, the adoption of the Law of Ukraine "On Insurance Mediation". Third: adding the relevant section to the drafted law "On Insurance". This can be done by the Federation of Insurance Mediators of Ukraine, the National Financial Services Commission, and the Verkhovna Rada of Ukraine. Fourth: disclosure of the requirements for a training program for insurance agents on the website of the National Financial Services Commission. Fifth: for the Ukrainian insurance market, it is expedient for insurers to train their agents independently. Sixth: public discussion of the issues of certification of insurance agents in Ukraine, involving representatives of various insurance companies, authorities, associations of insurance activity entities, mass-media, etc. Seventh: the creation of a single electronic registry of insurance mediators in Ukraine. Here the Ministry of Justice of Ukraine is the authorized body. Eighth: it is advisable to test insurance agents throughout the territory, submit the results to the supervisor. Ninth: Based on the results of testing, the National Financial Services Commission, being the authorized body, enters the data on insurance agents into a single state register. In general, the process of introducing certification will be long and eventful. It should be accompanied by the development of certification requirements for insurance agents. It is necessary to take into account the insurance agent's passing of the training course in the insurance company by specialization; applying for examinations and its payment (for example, it is 150 zloty in Poland, and up to $60 \$$ in the USA, successful completion of the exam, verification by the authorized body within 30 days of all documents and placing/or not placing of the insurance agent in a single register of insurance intermediaries. Afterward, the agent can carry out his insurance activity, already being present in the database. It is necessary to create a register of insurance agents, which will certify the level of their development in Ukraine. Introduction of certification of insurance agents requires the amendment of the current normative legal acts, their coordination with the provisions of European regulations.

\section{Conclusions}

The Europeanization of the domestic regulatory mechanism needs to take into account the provisions of the new EU Directive No. 97, which regulates the activities of insurance (reinsurance) mediators and distributors. It is necessary to determine the individualsdistributors (insurance mediators) and the conditions of their registration in the regulatory legislation of Ukraine. Provisions on limiting the volume of insurance premiums, a list of insurance risks, regulation of insurance agents, insurance (reinsurance) brokers are eligible for Ukraine. The issues of development of mechanisms of efficiency control, assessment of knowledge, professional training of insurance (reinsurance) mediators, and employees of insurance (reinsurance) companies are relevant for Ukraine. Under the condition of legislative consolidation in the insurance market of Ukraine, it is possible to establish a requirement for insurance (reinsurance) mediators, entities for which the consignment of insurance products is not the main activity, to have a policy of professional liability insurance. The Code of Professional Ethics for Insurance Brokers, acting in Ukraine, is a response to the thesis of the Directive on fair, just, professional actions and their compliance with the client's interests. It is necessary to regulate at the legislative level the issues of remuneration of insurance distributors, the requirements for the mandatory conclusion of an agreement to provide consumers with information on the status of the seller of the insurance product, the type of remuneration; cross-selling. These are the main directions of adaptation of Ukrainian legislation to the European one in the context of European integration processes.

The adoption of the new Law of Ukraine "On Insurance" is of great significance that will allow introducing a new procedure for legislative regulation of insurance (reinsurance) mediation in the field of insurance; improving the system of legal support for the development of insurance mediation, its state regulation, monitoring the activities of insurers and insurance mediators. The existing drafted law takes into account the basic recommendations of Directive 2009/138/ EU of 2009, so it is necessary to align its provisions with the new Directive No. 97. The definition of the requirements for an insurance broker and insurance agency is of European nature that takes into account their professional level, training, work experience, and requirements for mediation by the insurance broker and insurance agency.

The implementation of the registration process for all categories of insurance mediators and the keeping track of statistics of their activities is relevant for Ukraine. This will evidence the adaptation to EU norms. Certification of insurance agents is the establishment of a level of education, training, professional skills, 
knowledge, the experience of a professional to confirm compliance with standards, requirements for the conduct of insurance activities. National certification conditions must be in line with EU laws. Introduction of certification of insurance agents increases the authority of professionals in the insurance market, payment for their labour; promotes the development of the insurance market; certifies the professionalism of insurance mediators; raises trust in them; meets the requirements of international insurance markets and labour markets; allows assessing the quality of mediator training; provides quality services to the insured; protects against fraud by insurance mediators, insuring parties or insurers.

\section{References:}

Certification Association "Russian Registry" (2015) Retrieved from: http://www.rusregister.ru/services/ staffcertification

Gabidulin I. (2012) Chto nuzhno izmenit v gosudarstvennom regulirovanii, chtoby institut strahovogo brokerazha razvivalsya $v$ Ukraine [What needs to be changed in the state regulation so that the insurance brokerage institution can be developed in Ukraine]. Retrieved from: http://dedal.ua/dbm.php/pablications

National Commission for the regulation of state financial services markets (2006-2017) Ohliad strakhovoho rynku [Overview of the insurance market]. Retrieved from: http://nfp.gov.ua/content/strahoviy-rinok.html

Pikus R. (2009) Mizhnarodnyi dosvid strakhovykh poserednykiv [International experience of insurance mediators]. Bulletin of the Taras Shevchenko National University of Kyiv, series: Economics, no. 107/108, pp. 20-23.

Tax Code of Ukraine: Law of Ukraine (2010) no. 2755, VI of 02.12.2010. Retrieved from: http://www.rada.gov.ua Prykaziuk N.V. (2013 a) Komparatyvnyi analiz rehuliuvannia diialnosti strakhovykh poserednykiv u sviti [Comparative analysis of regulating the activity of insurance mediators in the world]. Formation of market relations in Ukraine, no. 4 (143), pp. 143-149.

Prykaziuk N.V. (2010) Derzhavne rehuliuvannia strakhovoho sektoru Ukrainy: tendentsii ta perspektyvy rozvytku [State regulation of the insurance sector of Ukraine: trends and prospects of development]. Finance of Ukraine, no. 7 (176), pp. 101-108.

Prykaziuk N.V. (2013 b) Diialnist strakhovykh brokeriv $v$ Ukraini ta yii rehuliuvannia [The activity of insurance brokers in Ukraine and its regulation] Effective economy. Electronic Professional Edition, no. 2. Retrieved from: http://www.economy.nayka.com.ua/?op=1\&z=1780

Prykaziuk N.V., Gubankova O.O. (2013) Sertyfikatsiia strakhovykh ahentiv ta perspektyvy yii vprovadzhennia $v$ Ukraini [Certification of Insurance Agents and Prospects for its Implementation in Ukraine]. Investments: practice and experience, no.7, pp. 73-76. Retrieved from: http://nbuv.gov.ua/UJRN/ipd_2013_7_19

Draft Law of Ukraine (2012) "Pro strahyvannia" ["On Insurance”]. Retrieved from: http://w1.c1.rada.gov.ua/pls/ zweb2/webproc4_2?pf3516=1797-1\&skl=9

Rasshyalov D. (2008) Poserednytski posluhy u strakhuvanni [Intermediary services in insurance]. Bulletin of Taras Shevchenko National University of Kyiv, series: Economics, no. 106, pp. 35-37.

Association Agreement between Ukraine, on the one hand, and the European Union, the European Atomic Energy Community and their Member States, on the other hand from June 27, 2014 (2014). Verkhovna Rada of Ukraine. Retrieved from: http://zakon5.rada.gov.ua/laws/show/984 011

The Civil Code of Ukraine: Law of Ukraine No $\overline{435}$ IV of 16.01.2003 (2003). Retrieved from: http://www.rada.gov.ua

Sholoyko A. (2016) Rehuliuvannia strakhovoho poserednytstva v umovakh yevrointehratsiinykh protsesiv Ukrainy [Regulation of Insurance Mediation in the Conditions of European Integration Processes of Ukraine], Bulletin of Taras Shevchenko National University of Kyiv, series: Economics, no. 3 (180), pp. 32-36.

IDD. BIPAR (2016) Retrieved from: http://www.bipar.eu/en/key-issues-positions/from-imd-i-to-imd-ii 